\title{
The role of gender in corporate governance: A state-of-art review
}

\author{
Mohammad Reza Ghaeli*
}

Faculty of Computer Studies and Information Systems, Douglas College, New Westminster, Canada

\begin{tabular}{l}
\hline C H R O N I C L E \\
\hline Article history: \\
Received April 1, 2018 \\
Received in revised format May \\
112018 \\
Accepted June 162018 \\
Available online \\
June 162018 \\
\hline Keywords: \\
Gender \\
Corporate governance \\
Financial firm performance
\end{tabular}
A B S T R A C T

\begin{abstract}
This paper presents an overview on recent studies on the role of gender in corporate governance. We study the recent works on the relationship between gender and firms' financial performance as well as the relationship between gender and firms' interest in global warming. According to our survey, it appears that firms with the presence of females had more concerns on green gas effects than other male oriented corporations did. Moreover, according to our survey, when a female member joins the board of directors, most investors consider this as a positive signal for profitability. In other words, it appears that the presence of female contributes to firm's financial performance.
\end{abstract}

(C) 2017 by the authors; licensee Growing Science, Canada.

\section{Introduction}

The increased attention to women on corporate boards presents new challenges to governance research. The board of directors is one of internal governance mechanisms intended to secure shareholders and managers' interest are closely merged. Among the most substantial governance issues presently encountered by the modern firms are those associated with diversity, such as gender and experience, and independence of directors (Kang et al., 2007). While board diversity and independence have been an open research, most empirical studies on this topic have been restricted to US data and obviously the generalizability of such results may not be extended to national boundaries because of various regulatory and economic environments, cultural differences, size of capital markets, etc. The importance and value of different governance structures, including board diversity and independence, have to be tested in each country, and the influential factors have to be investigated (Kang et al., 2007).

The existence of women on boards of directors has been an issue for years. Various studies, based on data primarily from different countries with Anglo-Saxon corporate governance systems, have studied the effect of female board appointments on corporate performance. Campbell and Vera (2010) concentrated on the effect of female directors in Spain, where debate about this topic was intense for several reasons: first, the recommendation in 2006 by Spain's Unified Good Governance Code of positive discrimination in favor of female board appointments and the passing in 2007 of a Gender Equality Act by the Spanish parliament. They investigated the short and long-term effects of the

\footnotetext{
* Corresponding author.

E-mail address: rghaeli@nyit.edu (M.R. Ghaeli) 
appointment of female directors prior to these events by implementing an event study to consider the short-term stock market reaction to the appointment of female directors and a multiple regression method to evaluate the long-term effect on business value of female boardroom appointments. They determined that the stock market behaved positively in the short term to the announcement of female board appointments, recommending that investors on average believe that female directors could create more add. This belief indicates to be confirmed by some regression results, which indicate that female board appointments were positively related to firm value over a sustained period.

\section{Green gas effect}

Some managers and regulators may be interested in improving corporate governance practices and climate-change strategies and wish to know the effects of gender on this regulations. Greenhouse gas emissions measurement and its disclosure to investors could be considered as the first step for addressing climate change problems and reducing the firm's carbon footprint.

Liao et al. (2015) investigated the effect of corporate board's characteristics on the voluntary disclosure of greenhouse gas (GHG) emissions in the form of a Carbon Disclosure Project report. They reported a positive relationship between gender diversity and the propensity to disclose GHG information as well as the extensiveness of that disclosure based on univariate and regression models based on a sample of the 329 largest firms in the United Kingdom. Moreover, a board with more independent directors or environmental committee in their survey represented a higher possibility to be ecologic transparent. Nevertheless, when the committee was not large enough, independent or active, its impact appeared meaningless. The results were consistent with stakeholder theory, recommending that a diversified and independent board and the existence of a board-level environmental committee could balance a firm's financial and non-financial objectives with limited resources.

Ben-Amar et al. (2017) studied the impact of existence of female on the board of directors on firm response to stakeholders' demands for increased public reporting about climate change-related risks. They depended on the Carbon Disclosure Project as a sustainability initiative supported by institutional investors. They determined that the possibility of voluntary climate change disclosure could go up with the presence of women on the boards and reported some evidence that supports critical mass theory with regard to board gender diversity based on a sample of publicly listed Canadian firms from 2008 to 2014.

Haque (2017) studied the impacts of board characteristics and sustainable compensation policy on carbon reduction initiatives and GHG emissions of corporation. They applied firm fixed effect model to analyze data from 256 non-financial UK companies from 2002 to 2014 . The results indicated that board independence and board gender diversity could positively related to carbon reduction initiatives. Moreover, environment-social-governance based compensation policy was also appeared to be positively related to carbon reduction initiatives. Nevertheless, they did not detect any association between corporate governance variables and GHG emissions of a firm and reported that corporate boards and executive management most likely concentrate on a firm's process-oriented carbon performance, without improving actual carbon performance in the form of reduced GHG emissions. The findings have important implications for practitioners and policymakers with respect to the effectiveness of internal corporate governance mechanisms in addressing climate change risks, and possible linkage between corporate governance reform and carbon related policies.

\section{Firm financial performance}

The monitoring role executed by the board of directors plays an important role on corporate governance control mechanism, especially in countries where external mechanisms are less well developed. The gender composition of the board may influence on the quality of this monitoring role and thus the financial performance of the firm. Campbell and Mínguez-Vera (2008) performed a comprehensive survey on selected firms in Spain for the relationship between firm financial performance and gender diversity and reported that investors in Spain would not penalize firms when they increase their female 
board membership and that bigger gender diversity could generate economic gains. Carter et al. (2010) performed an investigation on the business case for the inclusion of women and ethnic minority directors on the board. They studied the association between "the number of women directors and the number of ethnic minority directors on the board and important board committees and financial performance measured as return on assets and Tobin's Q" for a sample of major US corporations. They reported no significant association between the gender or ethnic diversity of the board, or important board committees, and financial performance. Their evidence also indicated that the gender and ethnic minority diversity of the board and firm financial performance could be endogenous. Nguyen et al. (2015) investigated the association between board gender diversity and firm financial performance in the context of a transitional economy characterized by an underdeveloped corporate governance system on 120 publicly listed firms in Vietnam from 2008 to 2011 using a dynamic modelling framework, which controlled for potential sources of endogeneity. They reported that board gender diversity maintained an effect on corporate performance and the results were even robust when alternative proxies for gender diversity were implemented and was consistent with the perspectives of agency theory and resource dependence theory. The number of female directors in the boardroom was also an issue, supporting the perspective that when female board representation influences on firm outcomes, this effect is more pronounced when the number of female directors goes up. It is also noticed, that the marginal positive performance effect of board gender diversity interrupted when the rate of female directors could reached a breakpoint of about $20 \%$. The results implied that there was a potential tradeoff between the costs and benefits of board gender diversification. The findings could substantially contribute to the growing literature of non-US based studies, by giving robust empirical evidence from a transitional economy in East Asia.

Kılıç and Kuzey (2016) performed an investigation to determine the board characteristics of some listed Turkish firms and tried to find the effect of board gender diversity on the performance of these firms. The study applied an instrumental variables regression analysis to study the association between board gender diversity and firm performance based on the data over the period 2008-2012. They reported that the boards of these firms in Turkey were male-dominated and the inclusion of female directors was positively associated with to the financial performance of companies, as measured by the return on assets, the return on equity and the return on sales. Choudhury (2014) argued that rationales for increasing women on boards should be based on both equality and economics grounds. The first is necessary as it describes the underlying problems which could rise to the lack of women on boards as well as empowers female representation to be valued in its own right, instead of in terms of business reform. Moreover, an economic rationale is also necessary to convince ardent sceptics. Wellalage and Locke (2013) studied demographic diversity of board members in the Sri Lankan boardroom and their impact on the firm financial performance. They reported that Sri Lankan corporate boards were not completely diversified in their gender, race and educational qualifications and achievements. They also reported that in Sri Lanka's uncertain environment, instead of having a diversified board, the preference was for recruitment to be concentrated on board members with the right skills.

Ahmadi et al. (2018) also reported a significant association between return on equities (ROE), return on assets (ROA) and the board of directors' composition and reported significant negative association between financial information and equity-based management compensation. Moreover, the presence of independent directors on the board appeared to influence, positively, the level of financial performance CAC 40 firms. Moreover, the stewardship theory assumption, the CEO duality was very high and was significantly related to a higher level of firm performance. The results recommended a constant negative association between firm performance and CEO's tenure. The results also indicated that there was a significant relationship between board gender diversity and firm performance from the samples of CAC 40 companies. Yahya and Shukeri (2014) investigated the effect of corporate governance on the firm financial performance among Malaysian Public Listed Companies and reported that board of director independence, qualification and female gender represent positive relationship with the firm performance while board size demonstrated negative relationship to firm performance. 


\section{Conclusion}

In this paper, we have reviewed the recent studies on the role of gender on corporate governance. The study focused on works, which were associated with the association of the presence of female on board of directors and green gas effects. According to our survey, it appears that firms with the presence of females had more concerns on green gas effects than other male oriented ones. The other part of the survey was associated with the role of gender and financial firm performance. In many studies, when a female member joined the board of directors, most investors considered this as a positive signal for profitability. In fact, many studies have indicated that the presence of female could contribute on firm performance.

\section{References}

Ahmadi, A., Nakaa, N., \& Bouri, A. (2018). Chief Executive Officer attributes, board structures, gender diversity and firm performance among French CAC 40 listed firms. Research in International Business and Finance, 44, 218-226

Ben-Amar, W., Chang, M., \& McIlkenny, P. (2017). Board gender diversity and corporate response to sustainability initiatives: evidence from the Carbon Disclosure Project. Journal of Business Ethics, 142(2), 369-383.

Campbell, K., \& Mínguez-Vera, A. (2008). Gender diversity in the boardroom and firm financial performance. Journal of business ethics, 83(3), 435-451.

Campbell, K., \& Vera, A. M. (2010). Female board appointments and firm valuation: Short and longterm effects. Journal of Management \& Governance, 14(1), 37-59.

Carter, D. A., D'Souza, F., Simkins, B. J., \& Simpson, W. G. (2010). The gender and ethnic diversity of US boards and board committees and firm financial performance. Corporate Governance: An International Review, 18(5), 396-414.

Choudhury, B. (2014). New rationales for women on boards. Oxford Journal of Legal Studies, 34(3), 511-542.

Gordini, N., \& Rancati, E. (2017). Gender diversity in the Italian boardroom and firm financial performance. Management Research Review, 40(1), 75-94.

Haque, F. (2017). The effects of board characteristics and sustainable compensation policy on carbon performance of UK firms. The British Accounting Review, 49(3), 347-364.

Kang, H., Cheng, M., \& Gray, S. J. (2007). Corporate governance and board composition: Diversity and independence of Australian boards. Corporate Governance: An International Review, 15(2), 194-207.

Kılıç, M., \& Kuzey, C. (2016). The effect of board gender diversity on firm performance: evidence from Turkey. Gender in Management: An International Journal, 31(7), 434-455.

Liao, L., Luo, L., \& Tang, Q. (2015). Gender diversity, board independence, environmental committee and greenhouse gas disclosure. The British Accounting Review, 47(4), 409-424.

Nguyen, T., Locke, S., \& Reddy, K. (2015). Does boardroom gender diversity matter? Evidence from a transitional economy. International Review of Economics \& Finance, 37, 184-202.

Wellalage, N. H., \& Locke, S. (2013). Corporate governance, board diversity and firm financial performance: new evidence from Sri Lanka. International Journal of Business Governance and Ethics, 8(2), 116-136.

Yahya, A. S. B., \& Shukeri, S. N. (2014). Corporate governance and firm financial performance for Malaysian public listed company. Advances in Environmental Biology, 383-389.

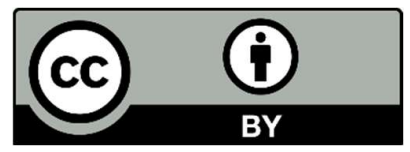

(C) 2019 by the authors; licensee Growing Science, Canada. This is an open access article distributed under the terms and conditions of the Creative Commons Attribution (CC-BY) license (http://creativecommons.org/licenses/by/4.0/). 